\title{
Changes in chlorophyll fluorescence parameters during desicca- tion and osmotic stress of Hassallia antarctica culture
}

\author{
Marta Campos Alonso* \\ University of Salamanca, Faculty of Biology, Campus Miguel de Unamuno, 37007 \\ Salamanca, Spain
}

\begin{abstract}
Hassallia antarctica is a terrestrial cyanobacterium colonizing various habitats in Antarctica such as soil surface, microbiological mats and seepages. H. antarctica represents one of the cyanobacterial species forming biodiversity of terrestrial autotrophs of James Ross Island, Antarctica. It is a filamentous cyanobacterium composing blackish fasciculated clusters thanks to false branching. In our study, sensitivity of the species to dehydration and salt stress was studied. We used $H$. antarctica culture (CCALA 956) grown on $\mathrm{Z}$ liquid medium. Clusters of $H$. antarctica were placed on wet filter paper and dried naturally at $5^{\circ} \mathrm{C}$. During gradual dehydration, relative water content (RWC) was evaluated gravimetrically simultaneously with chlorophyll fluorescence measurements. Slow Kautsky kinetics and the chlorophyll fluorescence parameters $\left(\mathrm{F}_{\mathrm{V}} / \mathrm{F}_{\mathrm{M}}, \Phi_{\mathrm{PSII}}\right)$ were used to assess dehydration-related decrease in primary photosynthetic processes. It was found that $H$. antarctica, contrastingly to other terrestrial cyanobacteria from polar habitats, was not able to maintain photosynthetic processes at RWCs as low as $20 \%$. Even during initial phase of dehydration (RWC of 95\%) rapid decline in $\mathrm{F}_{\mathrm{V}} / \mathrm{F}_{\mathrm{M}}$ occured. Resistance of $H$. antarctica to osmotic stress was studied by time courses of the chlorophyll fluorescence parameter in response to $3.0,0.3$, and $0.03 \mathrm{M} \mathrm{NaCl}$ solution. Both shape of slow Kautsky kinetics and numeric values of chlorophyll fluorescence parameters were affected by osmotic stress. While full inhibitory effect was apparent in $3.0 \mathrm{M} \mathrm{NaCl}$ treatment immediately, the salt stress-induced decline in chlorophyll fluorescence parameters was observed at $0.03 \mathrm{M} \mathrm{NaCl}$ even after 8 hours of exposition. It was, therefore, concluded that $H$. antarctica exhibited high resistance to osmotic stress which may help the species to cope with repetitive dehydration events that happen in the field during austral summer season in Antarctica, James Ross Island in particular.
\end{abstract}

Key words: cyanobacterium, Antarctics, James Ross Island, dehydration, Kautsky kinetics

DOI: $10.5817 / \mathrm{CPR} 2018-2-16$

\footnotetext{
Received July 3, 2018, accepted December 10, 2018.

*Corresponding author: M. C. Alonso <marta.campos@usal.es>

Acknowledgements: The authors are grateful to the CzechPolar2 infrastructure (LM2015078) for providing the laboratory facilities and support of the study. Special thank are expressed to A. Fernandez Iglesias for microphotographs that were taken thanks to the exploitation of the ECOPOLARIS project infrastructure (CZ.02.1.01/0.0/0.0/16_013/0001708).
} 
Symbols and abbreviations: ChlF - chlorophyll fluorescence, $\mathrm{F}_{\mathrm{V}} / \mathrm{F}_{\mathrm{M}}$ - potential yield of photochemical reactions in photosystem II, $\Phi_{\mathrm{PSII}}$ - effective quantum yield of photochemical processes in photosystem II, KK - slow Kautsky kinetics of chlorophyll fluorescence recorded for $5 \mathrm{~min}$. under moderate (actinic) light, OJIP - fast chlorophyll fluorescence transient, PS I - photosystem I, PS II - photosystem II

\section{Introduction}

Hassallia antarctica is reported from Antarctica, wet terrestrial habitats at James Ross Island, in particular (Komárek et al. 2015). It grows in similar localities as $H$. andreassenii but, unlike it, $H$. antarctica loosely attached to the stony substrate. This cyanobacterium is found typically in stone crevices and thrives well in freshwater microreservoirs formed between stony blocks in the littoral zone of lakes. The species is found also in seepages (in water among stones) or on dripping rocks. Komárek et al. (2012) reported a wide distribution in coastal Antarctica and wide ecological plasticity of the species compared to $H$. andreassenii.

In the traditional taxonomic system of cyanoprokaryotes, Hassallia genus has been neglected. Based on morphological characteristics, various species of this genus were mis-identified as belonging to the genera Tolypothrix and Coleodesmium. Parallel arrangement of the filaments in colonies and the morphology of trichomes are typical for Hassallia sp., however, may lead to a confusion with Coleodesmium sp. The genus Hassallia was revised recently according to the modern cyanobacterial system using molecular analyses and its diacritical features were well defined. Genus Hassallia belongs to Nostocales, the family of Microchaetaceae. Komárek et al. (2012) reports the genus Hassallia appears widely in coastal and maritime Antarctica (H. antarctica, $H$. andreassenii). The authors also describe the interspecific differences in anatomical and morphological structure between $H$. antarctica, $H$. andreassenii.

Physiological characteristics of the species of Hassallia genus have yet been stud- ied incompletely with the main emphasis given to the synthesis of specific biomolecules in Hassallia sp. Neuhof et al. (2005) studied Hassallidin A, a glycosylated lipopeptide with antifungal activity isolated from Hassallia sp. Physiological and molecular-biology aspects in resistance of cyanobacteria to salt stress were investigated by e.g. Winckelmann et al. (2015) in Cyanobacterium aponinum, a species competing with target algae in open pond bioreactor cultivations.

Responses of Hassallia sp. to variation of ecological factors forming physical environment have not yet been studied. It is assumed, however, that, similarly to other terrestrial autotrophic microorganisms from polar regions, $H$. antarctica may show a high resistance to desiccation. Therefore, we hypothesized that $H$. antarctica is capable to maintain photosynthetic processes even at low water content because it has been documented for several algae (e.g. Pichrtová et al. 2014, Herburger et al. 2015, Kaplan et al. 2013, Sadowsky et al. 2016), cyanobacteria (Obbels et al. 2013) and microbiological mats (Lionard et al. 2012) from polar regions. In our study, we focused on primary photosynthetic processes in $H$. antarctica affected by manipulating osmotic stress. We hypothesized that the species may exhibit a high resistance to moderate osmotic stress. To study the response of the photosynthetic apparatus to osmotic stress caused by the addition of sodium chloride into $H$. antarctica culture, we used chlorophyll fluorescence measurements with the consequent analysis of chlorophyll fluorescence parameters. 


\section{Material and Methods}

\section{Species description}

In our study, we used $H$. antarctica (J. Komárek, L. Nedbalová \& T. Hauer) from the Culture Collection of Autotrophic Organisms (CCALA, Species Ref. No. 956), Centre for Phycology, Institute of Botany, Třeboň, Czech Republic. Originally, the species was collected from a stony litoral of the Green lake ( $63^{\circ} 54^{\prime} 10^{\prime \prime} \mathrm{S}$, $\left.57^{\circ} 46^{\prime} 51^{\prime \prime} \mathrm{W}\right)$, James Ross Island, Antarctica.

Morphological structure of $H$. antarctica was described by Komárek et al. (2015). H. antarctica possesses heteropolar filaments. In the field, the species grows typically in macroscopic, dark brown up to blackish fasciculated clusters, with false branching and branches slightly and irregularly divaricated. Filaments and branches exhibit more or less the same morphology. They are cylindrical, having the width of $11.2-17.5 \mu \mathrm{m}$. The cylindrical cells of
H. antarctica, might be up to shortly barrel-shaped, always distinctly shorter than wide. Colour of the cells is blue-green or olive green, with slightly, irregularly granulated content. Terminal cells are rounded, sometimes larger than vegetative cells, longer and with hyaline content. Sheaths of cells are firm, relatively thick, laminated, yellowish to yellow-brown, cylindrical, closed at the apex. Trichomes are cylindrical, not constricted up to slightly constricted at the cross-walls. Trichomes are (7.4)8.6-12.3 $\mu \mathrm{m}$ wide. Heterocytes of $H$. antarctica are mainly basal, intercalary (usually before the false branching), solitary or in pairs, rarely up to 3 in a row, hemispherical, rarely up to oval. Akinetes are not known for the species. Reproduction of $H$. antarctica happens by hormogonia, mostly 7-8 $\mu \mathrm{m}$ wide, (2)4-12(14)celled.
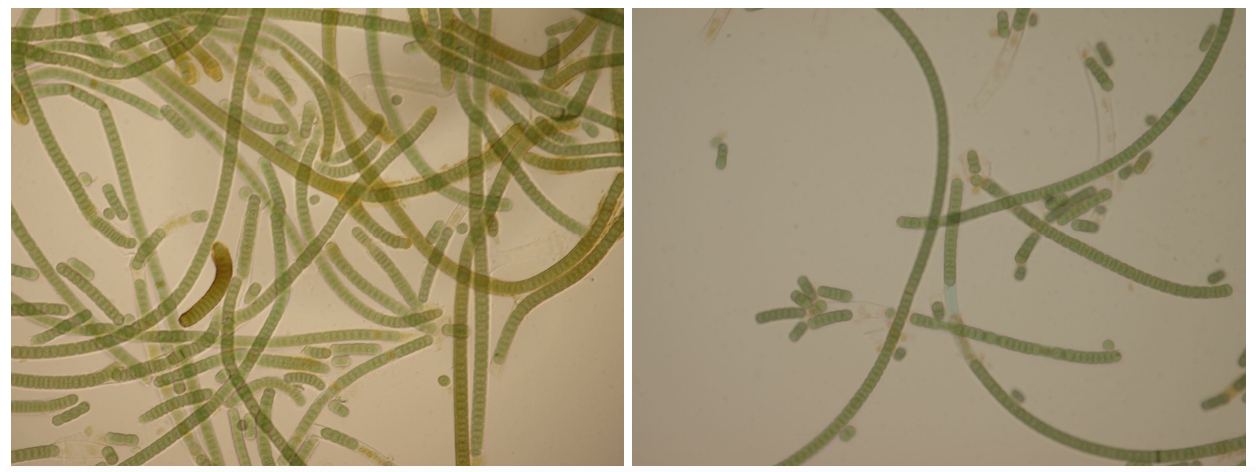

Fig. 1. Cultured Hassallia antarctica (strain CCALA 956) in liquid Z medium in the EEL laboratory. Photo by Antia Fernandez Iglesias.

\section{Cultivation}

Before experiments, $H$. antarctica was cultivated in $100 \mathrm{ml}$ flasks with $50 \mathrm{ml}$ of $\mathrm{Z}$ cultivation medium (Zehnder in Staub 1961) at $10^{\circ} \mathrm{C}$, under the irradiance of $15 \mu \mathrm{mol} \mathrm{m}^{-2} \mathrm{~s}^{-1}$ of photosynthetically active radiation. $\mathrm{Z}$ medium consisted of $\mathrm{NaNO}_{3}$, $\mathrm{Ca}\left(\mathrm{NO}_{3}\right)_{2} \cdot 4 \mathrm{H}_{2} \mathrm{O}, \mathrm{K}_{2} \mathrm{HPO}_{4}, \mathrm{MgSO}_{4} \cdot 7 \mathrm{H}_{2} \mathrm{O}$, $\mathrm{Na}_{2} \mathrm{CO}, \mathrm{Fe}-\mathrm{EDT}$ A solution, and trace metal solution (for details see Andersen 2005). 


\section{Desiccation and osmotic stress}

Before desiccation, clusters of $H$. antarctica colonies were taken from cultivation medium and placed on the disk-shaped wet filter papers $(3 \mathrm{~cm}$ in diameter). At this point, the culture was weighted (Mettler AE 100, Mettler-Toledo, Greifensee, Switzerland) and considered to have the relative water content (RWC) of $100 \%$. Then, the colonies were let to follow natural atmospheric dehydration at laboratory temperature $\left(23^{\circ} \mathrm{C}\right)$ and relative air humidity of $80 \%$. During gradual dehydration, the weight of colonies was evaluated regularly. To calculate the RWC of the colonies, the samples were weighted until they reach-

\section{Chlorophyll fluorescence measurements}

The changes in the physiological state of $H$. antarctica during the exposition period were evaluated by chlorophyll fluorescence imaging approach (HFC-010 Handy FluorCam, Photon Systems Instruments, Czech Republic). The microbiological plates with algal cultures (control, additional $0.03,0.3$, and $3.0 \mathrm{M} \mathrm{NaCl}$ ) were dark-adapted for 5 minutes to allow PS II centres to fully oxidize and be open for energy transfer. After the predarkening, slow Kautsky kinetics supplemented with saturation pulses (quenching analysis) were measured after 5, 30, 60, 120, 180 and 300 min. of $\mathrm{NaCl}$ exposition. We used the meth-

\section{Results and Discussion}

\section{Desiccation stress}

Both $\mathrm{F}_{\mathrm{V}} / \mathrm{F}_{\mathrm{M}}$ and $\Phi_{\mathrm{PSII}}$ declined rapidly even under initial phase of desiccation, i.e. with the RWC fall from 100 to $90 \%$. Raanan et al. (2016) measured $F_{V} / F_{M}$ and oxygen evolution rate in response to light and classified cyanobacteria as desiccationtolerant, semi-tolerant, and sensitive. They ed a constant (dry) weight. The RWC for a particular hydration state of the colony was calculated according to the equation:

$\mathrm{RWC}=\mathrm{m}_{(\mathrm{t})}-\mathrm{m}_{(\text {dry })} / \mathrm{m}_{(\text {wet })}-\mathrm{m}_{(\text {dry })} \quad$ Eqn. 1

where $m_{(t)}$ represents the weight of partially-dehydrated sample at the time of measurement (after substraction of the filter paper weight), $\mathrm{m}_{\text {(dry) }}$ and $\mathrm{m}_{\text {(wet) }}$ denote the weight of fully-dehydrated and fullyhydrated sample, respectively. Chlorophyll fluorescence was measured at particular RWCs using a standard protocol (see below).

od and experimental set up optimized for lichens and described elsewhere, see e.g. Trnková et Barták (2017). From the curves, particular chlorophyll fluorescence signals (see Fig. 2) and the following chlorophyll fluorescence parameters were evaluated: potential yield of photochemical photosynthetic processes in PS II $\left(\mathrm{F}_{\mathrm{V}} / \mathrm{F}_{\mathrm{M}}\right)$, effective yield of photochemical photosynthetic processes in PS II ( $\left.\Phi_{\text {PSII }}\right)$, non-photochemical quenching of chlorophyll fluorescence (NPQ), and steady-state fluorescence $\left(F_{S}\right)$. Time courses of the chlorophyll fluorescence parameters were done by plotting them against the time of exposition.

considered Nostoc sp. desiccation tolerant. Main reason for that is the presence of extracellular polysaccharide layer, which is thought to play an important protective role against desiccation in Nostoc sp. (Shirkey et al. 2000). 
Our earlier study focused on desiccation tolerance in $N$. commune (Trnková et Barták 2017) reported constant $\mathrm{F}_{\mathrm{V}} / \mathrm{F}_{\mathrm{M}}$ at RWC range of $10-100 \%$ followed by a decline at RWC below $10 \%$. Data for H. antarctica (Fig. 2), however, indicate fast decline of $F_{V} / F_{M}$ values at the RWCs below 95\%. Such contrasting behavior found for $\Phi_{\text {PSII }}$ as well suggests a high sensitivity of $H$. antarctica primary photosynthetic processes to desiccation. In follow up studies in $H$. antarctica, attention will be payed also to recovery of $\mathrm{F}_{\mathrm{V}} / \mathrm{F}_{\mathrm{M}}$ and $\Phi_{\text {PSII }}$ since some cyanobacteria exhibit fast recovery (within $1 \mathrm{~h}$ ) when rewetted as proved by Lüttge et al. (1995) by chlorophyll fluorescence and gas exchange methods.

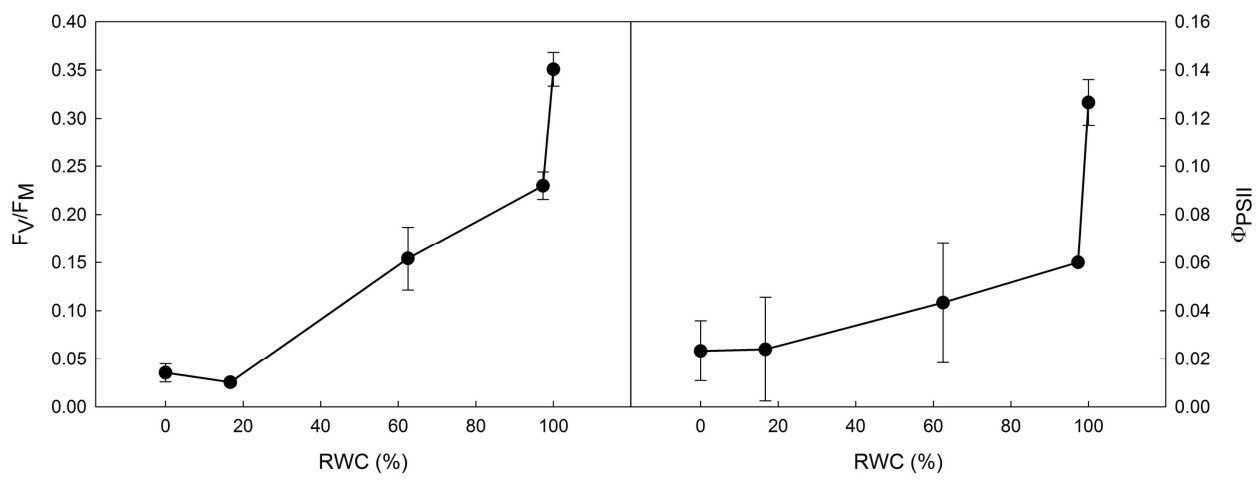

Fig. 2. Chlorophyll fluorescence parameters as dependent on relative water contents (RWC). Potential $\left(\mathrm{F}_{\mathrm{V}} / \mathrm{F}_{\mathrm{M}}\right)$ and effective $\left(\Phi_{\mathrm{PSII}}\right)$ quantum yield were recorded in desiccating $H$. antarctica from fully wet $(\mathrm{RWC}=100 \%)$ to dry state of culture $(\mathrm{RWC}=0 \%)$. Data points are means of three replicates. Error bars denote standard deviation.

In desiccation-tolerant cyanobacteria forming soil crusts, the mechanisms involved in the ability to cope with frequent hydration/desiccation cycles accompanied by oxidative stress in the cyanobacterial photosynthetic apparatus are largely unknown (Potts 2006). For individual cyanobacteria, they may consist of a specific proportion of (1) energy dissipation from photosynthetic apparatus by non-photochemical quenching, (2) involvement of enzymatic and non-enzymatic antioxidants, (3) cytochrome oxidase action - see Lafiti et al. 2009 for review. However, knowledge on the involvement of particular antioxidative mechanisms regulating the photosynthetic apparatus is still fragmen- tary for individual species. Recent studies give the main emphasis to avoidance of oxidative stress and photodamage in a cyanobacteria at wet state under excess illumination (e.g. Ohad et al. 2010, Kirilovsky 2015). In $H$. antarctica, such mechanisms are probably less developed and active during desiccation than in tolerant cyanobacteria. Such idea might be supported by the fact that $H$. antarctica was found and is reported from wet habitats. Therefore, desiccation events are probably not very frequent at such localities and the mechanisms involved to desiccation tolerance less developed than in e.g. Nostoc commune forming large colonies in seepages. 


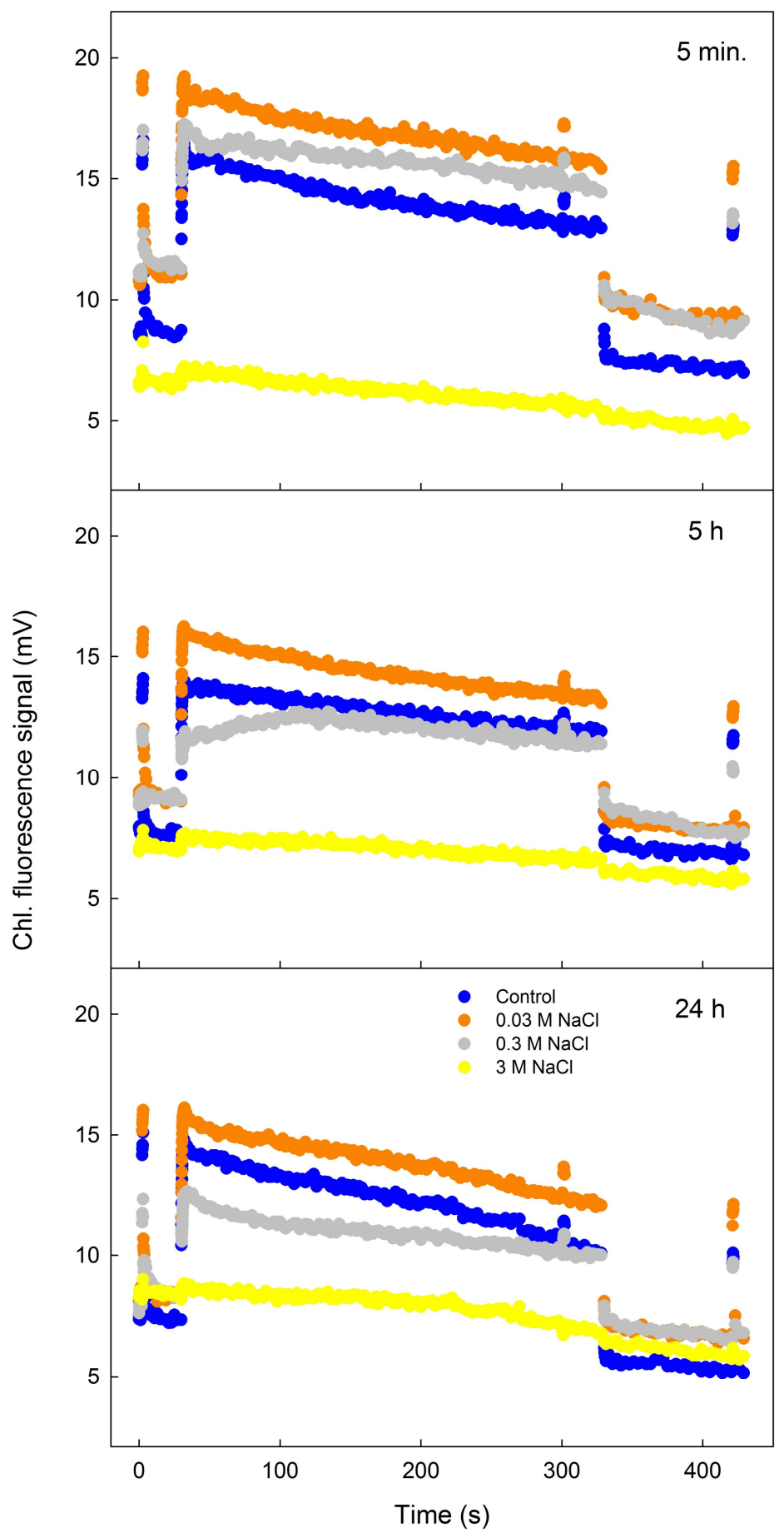

Fig. 3. Slow Kautsky kinetics of chlorophyll fluorescence recorded for $H$. antarctica under osmotic stress (blue $=$ control, orange $=0.03 \mathrm{M} \mathrm{NaCl}$, grey $=0.3 \mathrm{M} \mathrm{NaCl}$, yellow $=3.0 \mathrm{M} \mathrm{NaCl}$ ). 


\section{Osmotic stress}

Heavy salinity stress $(3.0 \mathrm{M} \mathrm{NaCl})$ strongly inhibited photosynthesis in $H$. antarctica which was reflected in extremely low values of $F_{\mathrm{V}} / \mathrm{F}_{\mathrm{M}}$ and $\Phi_{\mathrm{PSII}}$ (see Fig. 5), as well as the shape of slow Kautsky kinetics (KK) of chlorophyll fluorescence. Exposition to $3.0 \mathrm{M} \mathrm{NaCl}$ led to inhibition of photosynthetic processes even after 5 min. exposition, KK was typical of very low ChlF values $(5.0-7.0 \mathrm{mV})$ indicating negative effect of salt stress on chlorophyll molecules functioning and flattened shape of the KK, which is typical for heavily stressed plants including polar autotrophs (Barták et al. 2012, Trnková et Barták 2017 - Nostoc commune). Such phenomenon is well documented for salts stress effects monitored by KK and OJIPs (Lu et Vonshak 2002 - Spirulina platensis, Demetriou et al. 2007 - Scenedesmus obliquus, Jajoo 2014, and Kalaji et al. 2016 Triticum aestivum).

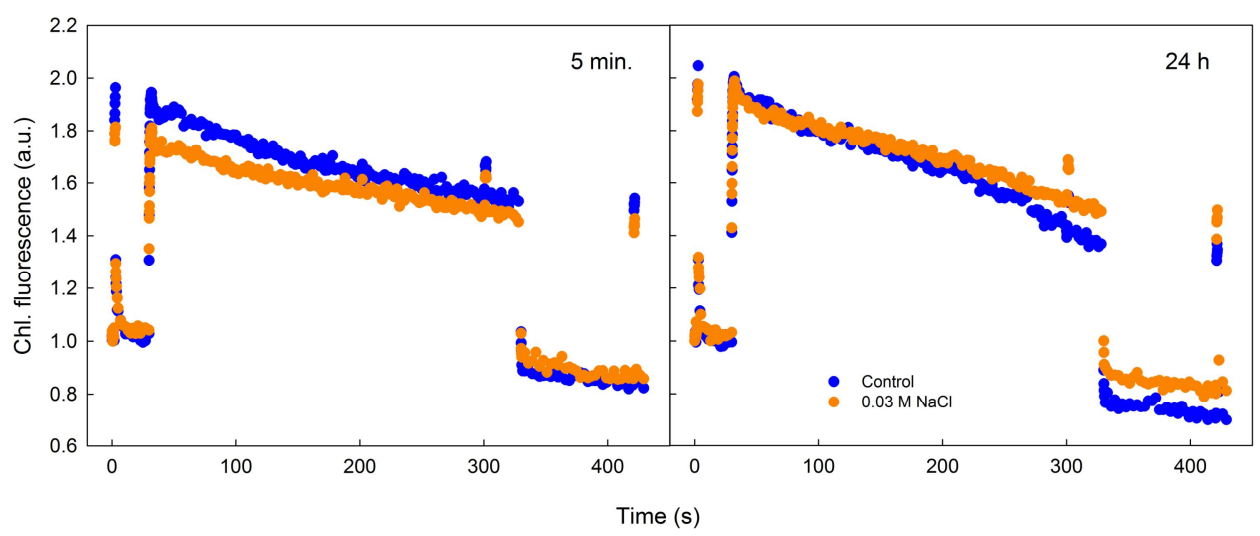

Fig. 4. Normalized Kautsky kinetics of chlorophyll fluorescence for control and $0.03 \mathrm{M} \mathrm{NaCl}-$ treated samples of $H$. antarctica.

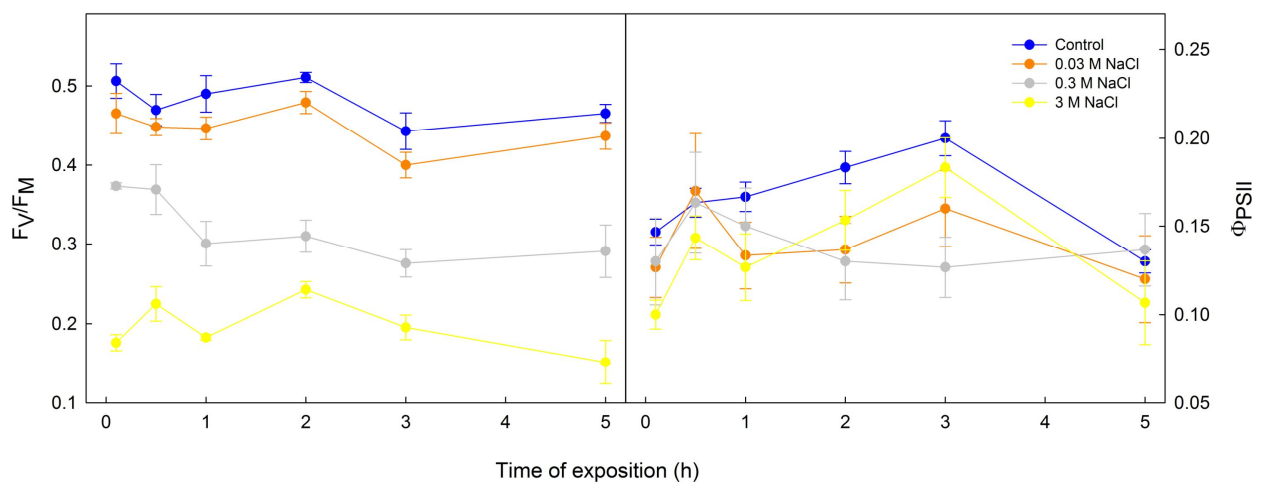

Fig. 5. Changes in ChlF parameters $\left(\mathrm{F}_{\mathrm{V}} / \mathrm{F}_{\mathrm{M}}\right.$ and $\left.\Phi_{\mathrm{PSII}}\right)$ under salt stress (blue $=$ control, orange $=$ $0.03 \mathrm{M} \mathrm{NaCl}$, grey $=0.3 \mathrm{M} \mathrm{NaCl}$, yellow $=3.0 \mathrm{M} \mathrm{NaCl}$ ) lasting for $5 \mathrm{~h}$. 
Then, with time of exposition to $\mathrm{NaCl}$, the $\mathrm{KK}$ in samples affected by $3.0 \mathrm{M} \mathrm{NaCl}$ remained of similar shape but ChlF values increased slightly $(6.0-8.0 \mathrm{mV})$ indicating ChlF emission from photosynthetically inactive chlorophyll molecules (resulting from a heavy salt stress). Moderate salt stress $(0.3 \mathrm{M} \mathrm{NaCl})$ led to a decrease in $\mathrm{ChlF}$ signal in $\mathrm{KK}$ compared to control and the $0.03 \mathrm{M} \mathrm{NaCl}$ treatment. With the time of exposition, ChlF signal decreased in $H$. antarctica treated with $0.3 \mathrm{M} \mathrm{NaCl}$

\section{Concluding remarks}

In our study, primary photosynthetic proceses in $H$. antarctica, functioning of PS II in particular (see $\Phi_{\text {PSII }}$ in Fig. 5), exhibited substantial resistance to moderate osmotic stress induced by $\mathrm{NaCl}$ addition. In literature, however, a wide range of PS II responses cyanobacteria of salt stress has been reported. While a decrease of PS II activity was found by e.g. Schubert et al. (1993), no effect of salinity stress on PS II activity was reported by e.g. Jeanjean et al. (1993). Recently, an accumulated evidence from several studies suggests that heavy short-term salt stress shock leads to multiple negative effects on PS II function in cyanobacteria ( $\mathrm{Lu}$ et Vonshak 2002). The authors reported limitation of electron transport at both donor and acceptor sides of PS II, which is accompanied by a damage to phycobilisome. The authors also suggested shifted distribution of excitation energy in favour of PS I which is typically accompanied by an increase in non-photochemical quenching. Similar response was described in Spirulina from the range of 14.0-17 $\mathrm{mV}$ (after $5 \mathrm{~min}$. exposition) to $10.0-13.0 \mathrm{mV}$ (after $24 \mathrm{~h}$ exposition). These changes indicated gradual (partial) inhibition of photosynthetic processes in $H$. antarctica under moderate salt stress. Exposition to $0.03 \mathrm{M} \mathrm{NaCl}$ did not bring any changes to the shape of KKs. When normalized to background chlorophyll fluorescence $\left(\mathrm{F}_{0}\right)$, the KKs in control and $0.03 \mathrm{M} \mathrm{NaCl}$-treated samples were quite similar (see Fig. 4).

patensis by Sudhir et al. (2005), showing a decrease in PS II mediated activity and an increase in PS I activity. Such phenomenon is typically attributed to changes in the thylakoid membrane protein profile and, consequently, decreased energy transfer from LHCs to PS II. In this concept, salt-adapted cells can maintain a high conversion efficiency of excitation energy through the down regulation of PS II RCs (Lu et Vonshak 2002). Our study suggests that a high dose of $\mathrm{NaCl}$ induces negative changes to the photosynthetic apparatus of cyanobacterium $H$. antarctica. The changes are indicated by altered shape of slow Kautsky kinetics of chlorophyll fluorescence, limitation of PS II functioning, $\mathrm{F}_{\mathrm{V}} / \mathrm{F}_{\mathrm{M}}$ in particular. The finding fits well to the experimental evidence for cyanobacteria and higher plants, in which addition of high doses of $\mathrm{NaCl}(0.5 \mathrm{M})$ and sorbitol $(1.0 \mathrm{M})$ were found to inactivate both PS II and PS I (Allakhverdiev et al. 2000, 2002).

\section{References}

Allakhverdiev, S. I., Sakamoto, A., Nishiyama, Y., Inaba, M. and Murata, N. (2000): Ionic and osmotic effects of $\mathrm{NaCl}$-induced inactivation of photosystems I and II in Synechococcus sp. Plant Physiolology, 123: 1047-56.

Allakhverdiev, S. I., Nishiyama, Y., Miyairi, S., Yamamoto, H., Inagaki, N., Kanesaki, Y. and Murata, N. (2002): Salt stress inhibits the repair of photodamaged photosystem II by 
suppressing the transcription and translation of psba genes in Synechocystis. Plant Physiolology, 130: 1443-1453.

ANDERSEN, R. A. (2005): Algal culturing techniques. Elsevier, Amsterdam, 578 p.

BARTÁK, M., HÁJEK, J. and OČENÁŠOvÁ, P. (2012): Photoinhibition of photosynthesis in Antarctic lichen Usnea antarctica. I. Light intensity-and light duration-dependent changes in functioning of photosystem II. Czech Polar Reports, 2(1): 42-51.

Demetriou, G., Neonaki, Ch., Navakoudis , E. and KotZabasis, K. (2007): Salt stress impact on the molecular structure and function of the photosynthetic apparatus- The protective role of polyamines. Biochimica et Biophysica Acta (BBA) - Bioenergetics, 1767: 272-280.

Herburger, K., Lewis, L. A. and Holzinger, A. (2015): Photosynthetic efficiency, desiccation tolerance and ultrastructure in two phylogenetically distinct strains of alpine Zygnema sp. (Zygnematophyceae, Streptophyta): Role of pre-akinete formation. Protoplasma, 252(2): 571589.

JAJOO, A. (2014): Changes in photosystem II heterogeneity in response to high salt stress. In: S. I. Allakhverdiev, A. B. Rubin, V. A. Shuvalov (eds.): Contemporary problems of photosynthesis. Institute of Computer Science, Izhevsk-Moscow, Vol. 2, pp. 397-413.

Jeanjean, R., Matthi, H. C. P., Onana, B., Havaux, M. and Joset, F. (1993): Exposure of the cyanobacterium Synechocystis PCC 6803 to salt stress induces concerted changes in respiration and photosynthesis. Plant and Cell Physiology, 34: 1073-1079.

Kalaji, H. M., JajoO, A., Oukarroum, A., Brestič, M., ZivČÁk, M., Samborska, I. A., Cetner, M. D., LuKAsiK, I., GoltSEv, V. and LADLE, R. J. (2016): Chlorophyll a fluorescence as a tool to monitor physiological status of plants under abiotic stress conditions. Acta Physiologiae Plantarum, 38: 102.

Kaplan, F., Lewis, L. A., Herburger, K. and Holzinger, A. (2013): Osmotic stress in Arctic and Antarctic strains of the green alga Zygnema (Zygnematales, Streptophyta): Effects on photosynthesis and ultrastructure. Micron, 44(2-2): 317-330.

KIRILOvSKY, D. (2015): Photosynthesis: dissipating energy by carotenoids. Nature Chemical Biology, 11: 242-243.

KomÁrek, J., NedbalovÁ, L. and Hauer, T. (2012): Phylogenetic position and taxonomy of three heterocytous cyanobacteria dominating the littoral of deglaciated lakes, James Ross Island, Antarctica. Polar Biology, 35: 759-774.

Komárek, J., Genuário, D. B., Fiore, M. F. and Elster, J. (2015): Heterocytous cyanobacteria of the Ulu Peninsula, James Ross Island, Antarctica. Polar Biology, 38: 475-492.

Latifi, A., Ruiz, M. and Zhang, C. C. (2009): Oxidative stress in cyanobacteria. FEMS Microbiology Reviews, 33: 258-278.

Lionard, M., PÉquin, B., Lovejoy, C. and Vincent, W. F. (2012): Benthic cyanobacterial mats in the High Arctic: multi-layer structure and fluorescence responses to osmotic stress. Frontiers in Microbiology, 3: 140.

Lu, C., Vonshak, A. (2002): Effects of salinity stress on photosystem II function in cyanobacterial Spirulina platensis cells. Physiologia Plantarum, 114: 405-413.

Lüttge, U., Büdel, B., Ball, E., Strube, F. and Weber, P. (1995): Photosynthesis of terrestrial cyanobacteria under light and desiccation stress as expressed by chlorophyll fluorescence and gas exchange. Journal of Experimental Botany, 46: 309-319.

Neuhof, T., Schmieder, P., Preussel, K., Dieckmann, R., Pham, H., Bartl, F. and von Döhren, H. (2005): Hassallidin A, a glycosylated lipopeptide with antifungal activity from the cyanobacterium Hassallia sp. Journal of Natural Products, 68(5): 695-700.

Obbels, D., Verleyen, E., Tytgat, B., Elster, J., Strunecki, O., Wilmotte, A., Willems, A., SABBe, K. and Vyverman, W. (2013): The diversity and tolerance to osmotic stress of East Antarctic filamentous Cyanobacteria. Scientific congresses and symposiums: Poster. $11^{\text {th }}$ SCAR Biology Symposium. Barcelona, Spain.

OHAD, I., RAAnAN, H., Keren, N., TChernov, D. and Kaplan, A. (2010): Light-Induced changes within photosystem II protects Microcoleus sp. in biological desert sand crusts against excess light. Plos One, 55(6): e11000. https://doi.org/10.1371/journal.pone.0011000. 
PichrtovÁ, M., KulichovÁ, J. and Holzinger, A. (2014): Nitrogen limitation and slow drying induce desiccation tolerance in conjugating green algae (Zygnematophyceae) from polar habitats. PLoS One, 9(11): e113137. https://doi.org/10.1371/journal.pone.0113137.

Potтs, M. (2006): The anhydrobiotic cyanobacterial cell. Physiologia Plantarum, 97: 788794.

RaAnan, H., Oren, N., Treves, H., Keren, N., Ohad, I., Berkowicz, S.M., Hagemann, M., Koch, M., Shotland, Y. and KaPlan, A. (2016): Towards clarifying what distinguishes cyanobacteria able to resurrect after desiccation from those that cannot: The photosynthetic aspect. Biochimica et Biophysica Acta (BBA) - Bioenergetics, 1857: 715722.

Sadowsky, A., Mettler-Altmann, T. and Ott, S. (2016): Metabolic response to desiccation stress in strains of green algal photobionts (Trebouxia) from two Antarctic lichens of southern habitats. Phycologia, 55: 703-714.

Schubert, H., Fluda, S. and Hagemann, M. (1993): Effects of adaptation to different salt concentrations on photosynthesis and pigmentation of the cyanobacterium Synechocystis sp. PCC 6803. Journal of Plant Physiology, 142: 291-295.

Shirkey, B., Kovarcik, D.P., Wright, D.J., Wilmoth, G., Prickett, T.F., Helm, R.F., Gregory, E.M. and PotTs, M. (2000): Active Fe-containing superoxide dismutase and abundant sodF mRNA in Nostoc commune (cyanobacteria) after years of desiccation. Journal of Bacteriology, 182: 189-197.

SudhiR, P. R., Pogoryelov, D., Kovacs, L., Garab, G. and Murthy, S. D. (2005): The effects of salt stress on photosynthetic electron transport and thylakoid membrane proteins in the cyanobacterium Spirulina platensis. International Journal of Biochemistry and Molecular Biology, 38: 481-485.

TRNKOVÁ, K., BARTÁK, M. (2017): Desiccation-induced changes in photochemical processes of photosynthesis and spectral reflectance in Nostoc commune (Cyanobacteria, Nostocales) colonies from polar regions. Phycological Research, 65: 44-50.

Winckelmann, D., Bleeke, F., Bergmann, P. and Klock, G. (2015): Growth of cyanobacterium aponinum influenced by increasing salt concentrations and temperature. 3 Biotech, 5(3): 253260.

ZEHNDER in STAUB, R. (1961): Ernährungphysiologish-autökologische Untersuchung an den Planktonischen Blaualge Oscillatoria rubescens DC. Schweizerische Zeitschrift für Hydrologie, 23: 82-198. (In German). 